and advice. The difficulties which the Council had to face in its early years have now been largely overcome, and research stations have been provided and staffed, and are in full activity. The range of problems covers plants, insects, animal nutrition, soil, irrigation, forest and cold storage problems, all of which are important to Australian prosperity. The fear that activity would have to be curtailed owing to financial stringency necessitating a reduction in the Council's grant has been largely obviated by the readiness with which funds have been given by corporations, commercial companies and private persons.

\section{Bibliography of Greenland}

A BIBLIOGRAPHY of works on Greenland confined to authors born in Norway, as well as Icelandic authors prior to 1814 , has been compiled by $\mathrm{Mr}$. $\mathrm{H}$. Vartdal and published as No. 54 of the Skrifter om Svalbard og Ishavet. The list runs to nearly eight hundred entries, and subsequent to 1721 is arranged according to subjects. A full index facilitates use. The list certainly has value, but would have been far more useful if it had been compiled without reference to the nationality of the authors, since the greater part of the works on Greenland are by Danish writers.

\section{Bibliography of Seismology}

Mr. Ernest Tillotson, 23, Roseville Road, Leeds, 8, writes with reference to notes on this subject in Nature of June 29, p. 1070, and July 27, p. 138, that he has received from Mr. Ernest A. Hodgson, the author of the "Bibliography of Seismology", a number of forms to fill in with details of British publications on seismological subjects. With the aid of these forms, he hopes to keep the "Bibliography" as up to date as possible so far as authors normally resident in the British Isles are concerned. To this end Mr. Tillotson asks such authors to send to him at the above address any newly published seismological literature. It is probable that, whilst papers and books on seismology in the narrower sense have been included in the "Bibliography" already, papers on seismological prospecting or on such subjects as changes in level, or the growth of faults, or earthquake insurance, etc., may have been overlooked.

\section{International Navigation Congress}

THe sixteenth International Navigation Congress, which is to be held at Brussels on September 2-13, under the patronage of H.M. the King of the Belgians and the presidency of the Minister of Public Works, will discuss a number of questions and communications relating to inland and maritime navigation, including the regulation and treatment of rivers and canals and the protective works required at ports and harbours. The Belgian Government has invited all the States interested in the Association of International Navigation Congresses to send official delegations to Brussels for the occasion. The Secretary General of the Association is M. Joseph Millecam,
38 rue de Louvain, Brussels, from whom full particulars can be obtained of the meetings, and of the excursions to various installations and undertakings in Belgium and Holland.

\section{Announcements}

The National Trust has accepted an offer by the Countess Buxton of nearly 150 acres of the South Downs at Newtimber Hill. The gift includes down and mixed woodland (mainly beech) with exceptionally fine views to the north and west, including Chanctonbury and Cissbury Rings.

THE fifteenth International Congress of Medical Hydrology, Climatology and Geology will be held at Belgrade in October 1936 under the patronage of the Prince Regent. Further information can be obtained from the general secretary, Prof. M. Neskovitch, 3 rue Takowska, Belgrade.

THE second International Congress of Mental Hygiene will be held in Paris on July 27-31, 1936, with Prof. H. Claude as president of honour and Dr. E. Toulouse as president. The official languages will be French, English, German, Italian, Spanish and Portuguese. Typewritten copies of communications must be sent to the president of the executive committee, Dr. René Charpentier, 119 rue Peronnet, Neuilly-sur-Seine, France, not later than November 1, 1935. The subscription, which is 125 francs, should be sent to the treasurer, M. R. Demaclus, 27 rue de Londres, Paris.

THE first number of a new quarterly, Annals of Science, devoted to the history of science since Renaissance times, will be published by Messrs. Taylor and Francis, Red Lion Court, E.C.4, on January 15, 1936 under the editorship of Dr. D. McKie of University College, London, joint author of "The Discovery of Specific and Latent Heats"; Prof. Harcourt Brown, of Washington University, St. Louis, U.S.A., author of "Scientific Organisations in 17th Century France" ; and Mr. H. W. Robinson, assistant librarian of the Royal Society of London, co-editor of "The Diary of Robert Hooke".

Applications are invited for the following appointments, on or before the dates mentioned :

A junior scientific officer (physicist) at the Fuel Research Station, East Greenwich-The Establishment Officer, Department of Scientific and Industrial Research, 16, Old Queen Street, Westminster, S.W.1 (Aug. 27).

A research chemist in the Department of Agricul ture, Straits Settlements and the Federated Malay States-The Director of Recruitment (Colonial Service), 2 Richmond Terrace, Whitehall, S.W.1.(Aug. 31).

A lecturer in the Civil and Mechanical Engineering Department of the Woolwich Polytechnic, S.E.18The Secretary (Aug. 31).

An assistant lecturer in agriculture to the Cornwall County Council Education Committee-The Secretary, Education Department, County Hall, Truro (Sept. 10). 